\title{
HUBUNGAN POLA ASUH ORANG TUA \\ DENGAN KONSEP DIRI SISWA KELAS XI \\ SMA KRISTEN 1 SALATIGA
}

Santa Yopita Br Kemit

Program Studi Bimbingan dan Konseling, FKIP-UKSW Salatiga

\begin{abstract}
Abstrak
Konsep diri merupukan dimensi yang paling penting dalam kepribadian. Konsep diri adalah salah satu faktor yang mempengaruhi bagaimana seorang siswa bersikap dan berprilaku. Jika siswa tersebut memandang dir sendiri tidak mampu, tidak berdaya dan hal negatif lainnya, akan mempengaruhi diri sendiri dalam berusaha. Selanjutnya konsep diri didefenisikan sebagai semua perasaan dan pemikiran sesorang mengenai diri sendiri, yang meliputi kemampuan, karakter diri, sikap, tujuan hidup, kebutuhan dan penampilan diri. Pola asuh orang tua turut memberi pengaruh yang signifikan terhadap konsep diri yang terbentuk. Orang tua sebgai tempat siswa bercerita dan menerima pendidikan untuk itu positif, negatif konsep diri siwa ditentukan oleh bagaimana pola asuh orang tua siswa tersebut.
\end{abstract}

Kata Kunci: Konsep Diri, Pola Asuh, SMA Kristen 1

\section{PENDAHULUAN}

Masa remaja merupakan masa yang sulit kerena pada masa tersebut remaja mulai mencari identitas diri atau jati diri, kedewasaan berpikir dan pembentukan kepribaadian mulai dibentuk pada masa ini. Konsep diri merupakan inti pola kepribadian yang mempengaruhi berbagai sifat, sehinggaa apabila sesoraang memiliki konsep diri yang positif, maka seseorang tersebut dapat mengembangkan sifat percaaya diri, harga diri, dan penyesuaian sosial yang baik. (Ariyani, 2004)

Pengalaman dan pola asuh orang tua turut memberi pengaruh yang signifikan terhadap konsep diri yang terbentuk. Sikap positif orang tua yang terbaca oleh anak, akan mengembangkan konsep diri dan pemikiran yang positif serta menghargai diri sendiri. Sikap negatif orang tua akan mengundang pertanyaan pada anak dan menimbulkan asumsi bahwa dirinya tidak cukup berharga utnuk dikasihi dan disayangi. Semua ini akibat kekurangan yang ada padanya sehingga orang tua tidak menyayanginya. (Rini. 2000).

Berdasarkan hasil pengamatan penulis selama melakukan Magang Bimbingan dan Konseling nampak 
bahwa setiap peserta didik kelas XI SMA Kristen 1 Salatiga pastilah memiliki konsep diri, baik itu konsep diri yang positif ataupun yang negatif. Selama peserta didik dalam lingkungan sekolah memang tidak ada pesertaa didik yang sempurna yang benar-benar sepenuhnya mempunyai konsep diri postif dan negatif. Untuk itu penulis ingin meneliti apakah konsep diri peserta didik dikarenakan pola pengasuhaan yang diterpakan oleh orang tua peserta didik tersebut? Hal inilah yang mendorong penulis untuk melakukan penelitian untuk mengetahui tingkat hubungan pola asuh otang tua dengan konsep diri peserta didik kelas XI SMA Kristen 1 Salatiga.

\section{KAJIAN TEORI}

\section{Konsep Diri}

Fitts (dalam Agustiani,2009) mengemukakan bahwa konsep diri merupakan aspek penting dalam diri seseorang, karena konsep diri merupakan kerangka acuan (frame of reference) dalam berinteraksi dengan lingkungan. Konsep diri secara fenomenologis ketika individu memper-sepsikan dirinya, bereaksi terhadap dirinya, memberikan arti dan penilaian serta membentuk abstraksi tentang dirinya, berarti bahwa individu menunjukkan sutu kesadaran diri (self awerness) dan kemampuan untuk keluar dari dirinya sendiri untuk melihat dirinya seperti yang dilakukannya terhadap dunia diluar dirinya.

Komponen konsep diri antara lain menurut William D. Brooks (dalam Rakhmat, 2004):

a) Komponen kognitif yang disebut juga citra diri (self image), konsep diri ini terbentuk dari pengalaman individu berinteraksi dengan orang lain. Melalui interaksi individu menemukan apa yang orang lain pikirkan tentang diri individu tersebut. Hal ini disebut dengan penaksiran yang direfleksikan. Penaksiran diri merupakan hal penting dalam pembentukan konsep diri. Penaksiran diri menunjuk pada ide bahasa individu menaksir diri sendiri dengan merefleksikan atau bercermin dari bagaimana orang lain menaksir diri individu tersebut. Jadi komponen kognitif ini berhubungan dengan pikiran 
yang meliputi, kecerdasan, daya tarik fisik, kepercayaan diri, tujuan hidup, kedudukan dan peran sosial serta kesukaan orang lain pada dirinya.

b) Komponen afektif yang sering disebut juga harga diri (self esteem), komponen ini berhubungan dengan perasaan. Komponen afektiif yang sering disebut juga harga diri meliputi penghargaan terhadap diri sebagai manusia yang memiliki tempat di lingkungan sosial. Penghargaan ini akan mempengaruhi dalam berinteraksi dengan orang lain. Komponen afektif yang disebut juga harga diri (Self Esteem) meliputi: perasaan, penyesuaian diri, penerimaan diri, penghargaan, pujian.

Berdasarkan

pendapat

Rakhmat (2004) tersebut dapat disimpulkan bahwa komponen konsep diri yaitu komponen kognitif dimana individu berinteraksi dengan orang lain dan menenmukan apa yang orang lain pikirkan tentang diri individu tersebut. Komponen konsep diri yang kedua yaitu komponen afektif atau disebut juga dengan harga diri merupakan penghargaan terhadap diri individu.

\section{Pola Asuh Orang Tua}

Menurut Brooks (dalam Rakhmat, 2004), pola asuh orang tua adalah sebuah proses dimana ada interkasi dan aksi antara anak dan orang tua, dan hal tersebut berlangsung hingga anak-anak berkembang menjadi dewasa. Hurlock (1999) menyatakan bahwa pola asuh orang tua aadalah metode yang digunakan oleh orang tua dalam hal ini untuk menjalin hubungan dan berkomunikasi dengan anak. Metode yang dimaksud merupakan metode yang mendidik, mengajar, membimbing untuk mengarahkan perilaku anak.

Hurlock (1999) menyatakan ada tiga macam cara yang digunakan oleh orangtua dalam mendidik anakanaknya yaitu pola asuh otoriter, pola asuh demokratis, dan pola asuh permisif. Dalam penerapannya tidak dapat dibedakan secara tegas sehingga kecendurngan pola asuh tertentu dapat diterapkan oleh orangtua kepada anak-anaknya. Ketiga pola asuh tersebut mempunyai model sebagi berikut: 
a) Pola asuh otoriter

Adanya kontrol yang ketat dari orangtua, aturan dan batasn dari orang tua harus ditaati oleh anak, anak harus bertingkah laku sesuai aturan yang ditetapkan orang tua, orang tua tidak mempertimbangkan pandangan atau pendapat anak dan orang tua memusatkan perhatian pada pengadilan secara otoriter yaitu berupa hukuman fisik. Pada tipe ini orangtua menentukan apa yang perlu diperbuat oleh anak tanpa memberi penjelasan tentang alasannya. Apabila anak melanggar ketentuan yang telah digariskan oleh orang tua, anak tidak diberi kesempatan untuk untuk memberi alasan atau penjelasan sebelum hukuman diterima anak. Pada umunya hukuman berwujud hukuman badan. Pada pola ini orang tua jarang atau tidak memberikan hadiah, baik berwujud kata-kata maupun bentuk lain apabila anak berbuat sesuai dengan orang tua. Tipe pola asuh otoriter anak mempunyai sifat submitif, anak tidak mempunyai inisiatif karena takut berbuat kesalahan, anak menjadi penurut, tidak mempunyai kepercayaan diri, dan tidak mempunyai tanggung jawab. Pada tipe ini kontrol orang tua ketat.

b) Pola asuh demokratis

Aturan yang dibuat bersama oleh seluruh anggota keluarga, orang tua memperhatikan keinginan dan pendapat anak, selalu mengadakan diskusi atau mengambil suatu keputusan, anak mendapat kesempatan untuk mengemukakan pendapatnya dan diberi kepercayaan serta ada bimbingan dan kontrol dari orang tua. Apabila anak harus melakukan tugas tertentu, orang tua memberikan penjelasan atau alasan perlunya hal tersebut dilakukan dan bila anak melanggar peraturan yang telah ditetapkan, anak diberi kesempatan untuk memberikan alasan mengapa ketentuan itu dilanggar sebelum anak menerima hukuman. Hukuman yang diberikan berkaitan dengan perbuatannya dan berat ringannya hukuman tergantung 
pada pelanggarannya. Hadiah atau pujian diberikan oleh orang tua untuk perilaku yang diharapkan.

c) Pola asuh permisif

Tidak adanya bimbingan dan aturan dari orang tua, tidak ada tuntutan kepada anak, tidak ada pengendalian atau pengotrolan dari orang tua. Orang tua tidak memberikan aturan kepada anaknya, anak diberikan kebebasan dan diijinkan untuk membuat keputusan untuk dirinya sendiri, anak harus belajar sendiri untuk berperilaku dalam lingkungan sosial, anak diperkenankan berbuat sesuai apa yang dipikirkan anak. Tidak ada hukuman dari orang tua meskipun anak melanggar peraturan dan tidak diberi hadiah bila berperilaku baik. Pada tipe serba boleh, karena tidak ada kontrol dari orang tua, anak dapat berbuat sekehendak hatinya, maka anak kurang respek terhadap orang tua, kurang menghargai apa yang diperbuat orang tua untuknya. Anak yang diasuh dan dididik dengan pola asuh ini biasanya dapat proteksi yang berlebihan, sehingga apapun yang dilakukan anak dibiarkan oleh orang tua. Dengan demikian perhatian serta hubungan orang tua dengan anak akan terganggu, karena tidak ada pengarahan atau informasi dari orang tua, maka anak tidak akan mengerti apa yang sebaiknya dikerjakan dan mana yang sebaiknya ditinggalkan. Anak kurang mempunyai tanggung jawab dan biasanya anak sulit dikendalikan serta berbuat halhal yang sebenarnya tidak dibenarkan. Perilaku sering melanggar norma-norma masyarakat karena itu akan terbentuk sikap penolakan dari lingkungan dan akibatnya kepercayaan diri goyah serta penghargaan diri sendiri kurang baik.

Dari uraian di atas penulis menarik kesimpulan bahwa orang tua yang berpola asuh otoriter memiliki ciri-ciri cenderung memberikan perintah dan larangan, menetapkan disiplin yang kaku, mengharuskan anak untuk patuh dan tidak boleh 
membantah orang tua, anak tidak mempunyai hak untuk berpendapat, bila bersalah anak harus dihukum, orang tua merasa paling benar dan anak yang disalahkan. Orang tua yang berpola asuh demokartis memiliki ciri-ciri keputusan dan aturan di rumah dibuat bersama oleh orang tua dan anak, ada bimbingan dan kontrol dari orang tua kepada anak, bila melakukan kesalahan anak akan mendapat peringatan atau hukuman dan bila anak berbuat baik akan mendapat pujian atau hadiah, pelaksanaan peraturan dan disiplin mempertimbangkan keadaan atau alasan dari anak yang dapat diterima oleh orang tua, hubungan keluarga sangat komunikatif dan hangat. Sedangkan orang tua menerapkan pola asuh permisif memiliki ciri-ciri tidak membimbing dan memonitor anak, tidak ada aturan yang digariskan oleh orang tua, anak bebas melakukan segala sesuatu, bila anak bermasalah tidak diberi hukuman, bila anak berbuat baik atau memenuhi harapan orang tua tidak diberi hadiah dan tidak ada kehangatan dalam hubungan keluarga.

\section{METODE PENELITIAN}

Hipotesis dari penelitian ini dapat dirumuskan sebagai berikut: "Ada hubungan pola asuh orang tua dengan konsep diri Siswa Kelas XI SMA Kristen 1 Salatiga". Untuk menganalisis data digunakan teknik analisis data kuantitatif. Dalam penelitian ini data yang dianalisis adalah variabel $\mathrm{X}$, yaitu pola asuh orang tua dan variabel $\mathrm{Y}$, yaitu konsep diri. Teknik analisis data yang digunakan dalam penelitian ini dengan menggunakan Korelasi Spearman Rank (melaui SPSS for Windows versi 20).

\section{HASIL PENELITIAN DAN PEMBAHASAN}

Tidak ada hubungan yang signifikan antara pola asuh orang tua otoriter dengan konsep diri siswa kelas XI SMA Kristen 1 Salatiga. Hal ini ditunjukkan pada nilai kofisien korelasinya $\mathrm{r}=0,462$ dengan nilai probabilitas atau 0,434 $>0,05$.

Hasil penelitian ini tidak ada hubungan yang signifikan antara pola asuh otoriter dengan konsep diri siswa kela XI SMA Kristen 1 Salatiga dimungkinkan pertanyaan 
dalam instrumen pola asuh orang tua otoriter memiliki makna yang tidak disukai oleh siswa seperti orang tua terlalu mengekang anak, kontrol yang ketat dari orang tua, aturan dan batasan dari orang tua harus di tatati oleh anak bahkan anak tidak diberi kesempatan memberikan alasan atau penjelasan sebelum hukuman di terima oleh anak.

Tidak ada hubungan yang signifikan antara pola asuh orang tua permisif dengan konsep diri siswa kelas XI SMA Kristen 1 Salatiga. Hal ini ditunjukkan pada nilai kofisien korelasinya $\mathrm{r}=0,038$ dengan nilai probabilitas atau 0,784 $>0,05$. Hasil penelitian ini tidak ada hubungan antara pola asuh permisif dengan konsep diri siswa kela XI SMA Kristen 1 Salatiga dimungkinkan pertanyaan dalam instrumen pola asuh orang tua permisif memiliki makna yang tidak disukai oleh siswa seperti orang tua tidak ada tuntutan aturan pengendalian, tidak ada hukuman dan tidak ada kontrol dari orang tua, dan anak dibiarkan sesuka hati dalam bertindak.
Temuan ini sesuai dengan hasil penelitian Robert, A dalam Shochib (1998) bahwa pengaruh negatif yang timbul antara pola asuh orang tua permisif dengan kenakalan remaja, orang tua bersikap tanpa kontrol kepada anak.

Ada hubungan yang signifikan antara pola asuh orang tua demokratis dengan konsep diri siswa kelas XI SMA Kristen 1 Salatiga. Hal ini ditunjukkan pada nilai koefisien korelasi $\mathrm{r}=0,350 * *$ dengan nilai probabilitas atau 0,000 $<0,05$ pada taraf 1\%. Hasil penelitian ini sejalan dengan hasil penelitian dari Layalia (2007) yang menemukan adanya hubungan pola asuh orang tua dengan konsep diri siswa SMA Negeri Se-Kota Blitar dimana hasil penghitungan dengan analisis regresi ganda menunjukkan bahwa ada hubungan yang signifikan antara pola asuh demokratis secara bersama-sama dengan konsep diri. Hasil temuan penelitian ini juga didukung dengan penelitian dari Reynold dalam Shocib (1998) menyatakan bahwa anak yang berhasil di sekolah adalah anak yang berlatar belakang dari keluarga yang 
berhubungan akrab, penuh kasih sayang, dan menerapkan disiplin berdasarkan kecintaan. Serta sesuai dengan penelitan yang diakukan oleh Hutabarat (2001) menunjukkan bahwa ada hubungan yang signifikan antara pola asuh orang tua tipe demokratik dengan harga diri dan ada hubungan yang signifikan antara pola asuh tipe pengabaian dengan harga diri. Menurut Rakhmat (2004) harga diri merupakan komponen afektif dari konsep diri, jadi ada hubungan yang positif antara pola asuh orang tua dengan konsep diri.

\section{PENUTUP}

Kesimpulan hasil penelitian ini dirumuskan sebagai berikut.

Tidak ada hubungan yang signifikan pola asuh orang tua otoriter dengan konsep diri siswa kelas XI SMA Kristen 1 Salatigadiperoleh nilaikoefisien korelasi $\mathrm{r}=0,462$ dengan nilai $\mathrm{p}=$ $0,434>0,05$.

Tidak ada hubungan yang signifikan pola asuh orang tua permisif dengan konsep diri siswa kelas XI SMA Kristen 1 Salatigadiperoleh nilaikoefisien korelasi $\mathrm{r}=-0,038$ dengan nilai $\mathrm{p}=$ $0,784>0,05$.

$$
\text { Ada hubungan yang }
$$

signifikan antara pola asuh orang tua demokratis dengan konsep diri siswa diperoleh koefisien korelasi $\mathrm{r}=$ $0,350 * *$ dengan nilai $\mathrm{p}=0,000<$ 0,01 .

\section{DAFTAR PUSTAKA}

Arikunto, Suharsimi. 2002. Prosedur Penelitian: Suara Pendekatan Praktis Jakarta : Rineka Cipta

Agustiani. 2009. Psikologi Perkembangan : pendekatan ekologi kaitannya dengan konsep diri dan penyesuaian diri pada remaja. Refika Aditama.

Dyah, P. 2004. Perbedaan Kemandirian Ditinjau dari Pola Asuh Orang Tua dan Jenis Kelamin Pada Siswa Kelas 1 SMU Negeri 1Ungaran Tahun Ajaran 2002/2003. Skripsi (tidak diterbitkan). Salatiga : Universitas Kristen Satya Wacana.

Hurlock E. B 2015. Perkembangan Anak Jilid 2. Jakarta : Erlangga

Hurlock, E. 1999. Psikologi Perkembangan Sutau Pendekatan Sepanjang Rentan Kehidupan. Jakarta : Erlangga

Hutabarat, M. T. 2001. Hubungan antara Pola Asuh dengan Harga Diri Sisiwa SLTP Kristen Satya Wacana Tahun Ajaran 
2000/2001. Skripsi (tidak diterbitkan). Salatiga : Universitas Kristen Satya Wacana

Praptasari, I. 2013. Hubungan Antara Konsep Diri Dengan Kemandirian Siswa Kelas VIII SMP Negeri 1 Bancak Kabupaten Semarang. Skripsi (tidak diterbitkan). Salatiga: Universitas Kristen Satya Wacana.
Rakhmat, J. 2004. Psikologi Komunikasi. Bandung : PT. Remaja Rosdakarya

Rini JF. 2000. Konsep Diri. http://www.epsikologi.com/dewasa/1605023. htm.

Saputra, ganda. 2015. Hubungan Pola Asuh Orang tua Denga Konsep Diri Siswa Kelas X1 SMA Kristen 1 Salatiga. Skripsi (tidak diterbitkan). Salatiga : Universitas Kristen Satya Wacana 